\title{
Influence of Pasteurization Methods on Nutritional Quality of Guava Pulp and Grape Juice
}

\author{
Ajit Kumar Singh*, V. R. Sagar, Shalini G. Rudra, S. K. Singh and Sunil Pabbi \\ ICAR-Indian Agricultural Research Institute, New Delhi110012, India \\ *Corresponding author
}

\section{A B S T R A C T}

\begin{tabular}{|l|}
\hline K e y w o r d s \\
Allahabad Safeda, \\
PusaNavrang, \\
Nutritional \\
composition, \\
Pasteurization \\
thermal, \\
Microwave, \\
Irradiation
\end{tabular}

\begin{abstract}
This study was conducted to standardize a processing method for the development of a protocol for making nectar from guava pulp and grape juice. The pulp of guava variety Allahabad Safeda and the juice of coloured grape variety, PusaNavrang juice was extracted and evaluated for quality parameters such as titratable acidity, TSS, ascorbic acid, total anthocyanins and phenol content. After this, guava pulp and grape juice were subjected to three different pasteurization processes such as microwave $(300,600$ and 900 $\mathrm{W}$ for $1 \mathrm{~min}, 30 \mathrm{Sec} \& 10 \mathrm{Sec})$, thermal $\left(70,80,90^{\circ} \mathrm{C}\right.$ based on POD inactivation) and irradiation $(0.5,1.0$ and1.5 kGy) to observe their effect of colour, flavour and quality. The nutritional composition of guava and grape revealed that guava fruit contained moisture (80\%), TSS $\left(9.5^{\circ}\right.$ Brix $)$, titratable acidity $(0.3 \%)$, ascorbic acid $(291 \mathrm{mg} / 100 \mathrm{~g})$, and reducing and total sugar $(2.90 \%)$ and $(4.6 \%)$, respectively. The recovery of pulp in guava fruits was $55 \%$. In case of grapes, moisture content was $(87 \%)$, TSS $\left(18^{\circ}\right.$ Brix $)$, titratable acidity $(0.35$ $\%)$ anthocyanin content $(40.2 \mathrm{mg} / 100 \mathrm{ml})$ and reducing and total sugar $(7.3 \& 8.2 \%)$, respectively. The recovery of juice in coloured grape was $68 \%$. The results showed that microwave pasteurization at $1.56 \mathrm{~W} / \mathrm{ml}$ juice $(300 \mathrm{~W} / 1 \mathrm{~min})$ was the best treatment in preserving the colour, flavour, taste and overall quality of both guava pulp as well grape juice which was used for preparing the anthocyanin-rich guava nectar.
\end{abstract}

\section{Introduction}

Tropical fruits are gaining popularity due to their potential health benefits and exotic flavours. Among the tropical fruits, guava and grape have a good production potential and are suitable for the production of a variety of products with good taste and flavour. Guava contains very high amount of vitamin $\mathrm{C}$, which helps in improving immunity and protects us from common infections and pathogens. Guava is widely cultivated all over the tropics and sub-tropical area of India. Its fruit consists of 20 per cent peel, 50 per cent pulp and remaining portion as seed core (Wilson, 1980). Guava fruit normally consumed as fresh as a dessert fruit due to excellent flavour, high digestive and nutritive value, high palatability and availability. Guava is often marketed as "super-fruits", which has a considerable nutritional importance in terms of vitamins $\mathrm{A}$ and $\mathrm{C}$. The high content of vitamin $\mathrm{C}$ (ascorbic acid) in guava makes it a powerhouse in combating 
free radicals and oxidation that are key enemies to many degenerative diseases. The high national production, the high rate of perishability and lack of appropriate technology are some of the factors responsible for the high amount of waste in the fruit processing sector. The addition of chemical food additives to these products in order to improve the colour, aroma, texture and flavour become necessary to benefit the food industry (Queiroz, 2006). Ripe guava fruits are highly perishable when stored at room temperature, but it can be processed into various commercial products, including pulp, paste, canned slices in syrup and juice. Among these products, guava juice has become economically important in the market. The consumption of tropical fruit juice like guava is currently growing because it is natural, rich in nutrients and used as an alternative to other beverages such as soft drinks, tea and coffee (Akesowan and Choonhahirun, 2013).

Coloured grapes have excellent pigment colour due to the presence of anthocyanins, phenols and betalains in their pulp. Both anthocyanins and phenols are the promising antioxidants. Which have excellent therapeutic properties and can prevent or reduce the incidence of a wide range of diseases or disorders associated with freeradicals or radical oxygen species (ROS) like Parkinson's disease, hypertensive cerebravascular injury, cataract genesis, ocular hemorrhage, atherosclerosis, various types of cancers, gastro-intestinal disorders hypoxia, disorders related to alcoholism and ultimately ageing (Rasines-Perea and Teissedre, 2017). Anthocyanins in fruits such as muscadine grapes and strawberries, polymerize with other polyphenolic compounds to increase color stability. Stability of anthocyanins pigment is also increased by storage at refrigerated temperatures $\left(4-7^{\circ} \mathrm{C}\right)$ (Bonaventura and Russo, 1993; Chia et al.,
2012). Fruit beverages are increasingly gaining popularity throughout the world due to nutritive and therapeutic value over synthetic beverages, as synthetic drinks contain only water (about 88\%), carbohydrates (about 12\%) and provide about 48 Kcal (Sethi and Sethi, 2006). Thus, fruitbased beverages are far more superior than many synthetic drinks. If synthetic drinks are replaced by fruit beverages, it would be a boon to the consumers as well as to the fruit growers. Moreover, fruit pulps and drinks have great export potential. Fresh fruits have limited shelf life due to the perishable nature of the fruits; they require immediate processing to avoid post-harvest losses. Therefore, it is necessary to utilize the fruits for making different products to increase their availability over an extended period and to stabilize the prices during the glut season.

\section{Materials and Methods}

Thefully mature fruits of guava $\mathrm{Cv}$ Allahabad Safeda and coloured grape (PusaNavrang) were procured from Main Fruit Orchard of the Division of Fruits and Horticultural Technology, IARI, New Delhi. The guavaand coloured grape were harvested at commercial stage of maturity, after harvesting and sorting, the fruits were packed in CFB boxes and stored at $\left(4 \pm 2^{\circ} \mathrm{C}\right)$ with $80-90 \%$ relative humidity at the Division of Food Science and Postharvest Technology, ICAR-Indian Agricultural Research Institute, New Delhi, to optimize the protocol for processing of guava and grape, uniform sized fruits were washed in under running tap water and divided in two lots, One lot was further divided in to three lots and given the treatments of irradiation (0.5, 1.0 and1.5 kGy), microwave (300, 600 and $900 \mathrm{~W}$ for 1Min., $30 \mathrm{Sec} . \& 10 \mathrm{Sec}$ ) and thermal(70, $80, \quad 90^{\circ} \mathrm{C}$ based on POD inactivation) treatments were used. Second lot was treated as control without any treatment to standardize the optimum treatment for 
getting maximum yield of pulp/juice from the fruits, The physical and bio-chemical parameters, viz., TSS, acidity, ascorbic acid, total anthocyanins, reducing sugar, total sugars and sensory evaluation were analysed at three days interval.

\section{Preparation of fruit juice}

Guava(Allahabad Safeda) fruits were harvested at the physiologically mature stage with free from insect, pest, disease and mechanical damages, however its fruits having a resemble shape, size and colour was selected and after harvest fruits were quickly transported in $\mathrm{CFB}$ boxes to processing laboratory for extraction of guava pulp in24hours. The fruits were properly washed using tap water, and after-treatment flesh of fruit was cut into halves using stainless steel knife and the seeds were removed and further juice was extracted by using fruit pulper (Bajaj Process Pack Limited, Fruit Processing and Packaging Technologies, Noida, Uttar Pradesh)

Grape berries were selected to having uniform shape, size and colour with free from insect, pest and diseases. However, berries were separated from rachis after harvest fruits were quickly transported in $\mathrm{CFB}$ boxes to processing laboratory therefore the fruits was properly washed using tap water, and after treatment pulp was further used for extraction of Juice was using fruit pulper (500-4000 Ib $\backslash \mathrm{In}^{2}$ Johnston Automation Co. Kirti Nagar, New Delhi 110015)The extracted juice was sieved to remove the seed and skin from the juice.

\section{Recovery of juice/pulp}

The juice/pulp obtained from both fruits had weighed to find out the per cent juice/pulp recovery as under

\section{Weight of juice/pulp} $-\times 100$

Juice/pulp (\%)=Total fruit weight

\section{Determination of physical attributes}

The sensory evaluation of the extracted juice was carried out with a sensory panel of $10-$ semi trained members and score was calculated on 9-point hedonic scale $(1=$ dislike extremely, $9=$ like extremely). to determine the influence of different physical treatment on nutritional quality of guava pulp and grape juice. The extracted juice/ pulp was evaluated by a panel of ten semi trained including faculty and post graduate students of department of Food Science and Postharvest Technology Division of ICARIARI NEW DELHI -110012. Evaluation was performed immediately after extraction of juice from fruits. The panellist's average response was calculated for each attribute. A score below 3 for any of the evaluated attributes indicated loss of acceptance from a sensory point of view (Alvarez et al., 2013).

\section{Estimation of bio-chemical attributes}

Different parameters like total soluble solids $\left({ }^{\circ}\right.$ Brix $)$, titratable acidity $(\%)$, ascorbic acid $(\mathrm{mg} / 100 \mathrm{~g} / \mathrm{ml})$, total monomeric anthocyanins $(\mathrm{mg} / \mathrm{L})$, total sugars $(\%)$ and reducing sugars (\%) were estimated employing standard procedures as under (Ranganna,1999).

\section{Total soluble solids (TSS)}

The total soluble solids (TSS) of sample were determined with a digital hand held refractometer (0-50 ${ }^{\circ}$ Brix A lago Japan) at $20^{\circ} \mathrm{C}$ by placing a drop of the filtered juice on the prism and result were recorded. Titratable acidity, ascorbic acid and anthocyanin $(\mathrm{pH}$ differential method) content of the sample were determined as per the standard 
procedures and denoted as percentage (\%), $\mathrm{mg} / 100 \mathrm{~g}$ pulp and $\mathrm{mg} / \mathrm{l}$, respectively (Ranganna,1999).

\section{Titratable acidity}

For the estimation of titratable acidity five $\mathrm{ml}$ the juice was titrated against $0.1 \mathrm{~N} \mathrm{NaOH}$ solution using phenolphthalein as an indicator in all the fruits except grape. The acidity in grape was measured by titrating a known volume of the juice against $0.1 \mathrm{~N} \mathrm{NaOH}$ to a $\mathrm{pH}$ of 8.1 with a glass electrode $\mathrm{pH}$ meter. The acidity was calculated and expressed as per cent citric acid (Ranganna, 1999).

\section{Ascorbic acid}

Ascorbic acid was estimated by using of dye (2,6-dichlorophenol indophenol) following the procedure of Ranganna (1999). For this, $2 \mathrm{ml}$ both of grape and guava juice was titrated with using $0.1 \%$ of 2,6 dichlorophenolindophenol solution dissolved in 3\% metaphosphoric acid to a appearance pink colour. The ascorbic acid concentration was calculated according to the titration volume of 2,6-dichloroindophenol and expressed as $\mathrm{mg} 100^{-1} \mathrm{~mL}$.

\section{Anthocyanin content}

The total anthocyanin content was determined by the $\mathrm{pH}$ deferential method. An aliquot (1 $\mathrm{mL}$ ) of diluted grape juice was taken in both $0.025 \mathrm{M}$ potassium chloride solution $(\mathrm{pH} 1.0$; $125 \mathrm{~mL}$ of $0.2 \mathrm{~N} \mathrm{KCL}(8.9 \mathrm{~g} / 500)$ and added with $385 \mathrm{~mL}$ of $0.2 \mathrm{~N} \mathrm{HCl}$ after adjusted to $\mathrm{pH}$ with concentrated $\mathrm{HCl}(36.5 \%)$ and $1 \mathrm{M}$ sodium acetate buffer $(68 \mathrm{~g} / 500$ $\mathrm{CH}_{3} \mathrm{CO}_{2} \mathrm{Na} \cdot 3 \mathrm{H}_{2} \mathrm{O}$ ) water adjusted top $\mathrm{H} 4.5$ with concentrated $\mathrm{HCl}(36.5 \%)$ to value was measured at both 510 and $700 \mathrm{~nm}$ after $20 \mathrm{~min}$ of incubation at $25^{\circ} \mathrm{C}$. The content of total anthocyanins was expressed as $\mu \mathrm{g}$ g cyanidin 3 -glucoside equivalents per $100 \mathrm{~mL}$ grape juice. A molar absorption coefficient of 26,900 Lmol-1 $\mathrm{cm}-1$ was used to calculate the concentration of cyanidin 3-glucosidein $\mathrm{n}$ grape juice (Wrolstad et al., 2005).

Total anthocyanin $(\mathrm{mg} / \mathrm{L})=\mathrm{A} \times \mathrm{MW} \times \mathrm{DF}$ $\times 10^{3}$

$\varepsilon \times \mathrm{L} \times \mathrm{m}$

Where,

$\mathrm{A}=\left(\mathrm{A}_{\max }-\mathrm{A}_{700}\right) \mathrm{pH} 1.0-\left(\mathrm{A}_{\max }-\mathrm{A}_{700}\right) \mathrm{pH} 4.5$

MW= Molecular weight

$\mathrm{DF}=$ Dilution factor

$\varepsilon=$ Molar extinction coefficient of pigment

$\mathrm{L} \times \mathrm{mol}^{-1} \times \mathrm{cm}^{-1}$

$\mathrm{L}=$ Pathlength $(1 \mathrm{~cm})$

$\mathrm{m}=$ weight

\section{Results and Discussion}

In order to standardize the pasteurization treatment, a preliminary experiment was carried out separately for guava and coloured grapes for each set of pasteurization method such as irradiation, microwave and thermal pasteurization are involving for increase the recovery of juice, healthy consumption and extending the shelf life without cause to undesirable changes such as loss of vitamins, essential nutrients and flavours, so that three combinations in each treatment were observations taken after each treatment and mean values were compared to select the best treatment.

\section{Recovery of pulp/juice}

The recovery of quantitative guava pulp increased with increase in irradiation doses 
from $0.5 \mathrm{kGy}$ to $1 . \mathrm{kGy}$ as shown in (Table 1 ). The maximum recovery of the extracted pulp was found in irradiated does of $1.0 \mathrm{kGy}$ $(57.81 \%)$ because of a high stream energy photon, can energize electrons within the atoms when it comes into contact over fruits, therefore, may cause to ionization or excitation. However, these ionized energy absorbed on fruits to causes the hydrolysis of pectin and followed by depolymerisation carbohydrates polymer, which are result in softer and sweeter of fruits, therefore due to the softening of the internal tissues, the yield of the fruit juice increases during processing (DA mour et al., 1993).Similarly, Betancurt et al., (2009) reported that the amount of juice obtained from oranges increased yield with the increased of irradiation dose. While in case of microwave $(300 \mathrm{~W})$ and thermal $\left(80^{\circ} \mathrm{C}\right)$ pasteurization doses, the maximum juicelpulp recovery was $62.12 \%$ and $59.53 \%$ respectively. Similarly, in case of grape the recovery of juice was $63.67 \%, 69.89 \%$ and $65.34 \%$ in irradiation, microwave and thermal pasteurization respectively. Among these method of pasteurization, recovery of juice was significantly higher in microwave than control and other methods of pasteurization (Bittar et al., 2013). This may be due to enhancement in the degradation of bound cell wall by microwave heating. Similarly, Betancurt et al., (2009) reported that the amount of juice obtained from oranges increased yield with the increased of irradiation dose.

\section{pomace $(\%)$}

Guava and grape pomace have been produced through pressing whole fruits during the extraction of juice. The amount of both fruits pomace yield depend on the maturity index, However in general about $20 \%$ of the mass of total processed grapes (Boussetta et al., 2009) It is very clear from Table 1 that pomace content decreased with the increase in irradiation doses and it was the higher in control samples. The maximum recovery of the extracted pomace was recorded in irradiation dose of $1.0 \mathrm{KGy}$. The effect of microwave on pomace percent during extraction of guava pulp decreased with increase in power level due to microwave pasteurization is based on the transformation of electromagnetic field energy into thermal energy by affecting the polar molecules of the material so that its leading to the degradation of pectic substances of the cell wall as compared to conventional heating. However, the minimum pomace $37.88 \% \mathrm{t}$ was obtained in $600 \mathrm{~W}$ treatment. Similarly, in case of thermal pasteurization, the pomace quantity decreased with increase in temperature, and it was maximum in control samples followed by samples pasteurized at with $70^{\circ} \mathrm{C}$, Threl fall et al., (2005)

\section{Total soluble solids ( ${ }^{\circ}$ Brix $)$}

TSS estimation was done for irradiated sample of guava and grape on initial day there was no significant observed n TSS level. Similar trends have been reported by Vanamala et al., (2007) in Pummlo fruits. Yook (2009) has also been reported no significant difference between irradiated and control ( 0 kGy) samples of kiwifruits. However, in case of microwave and thermal pasteurization, there was an increase in TSS after treatments. The increase in TSS might be due to the evaporation of water which causes concentrated the juice. Similar findings have also been reported by Kumar et al., (2017) in fresh pummelo juice. A significant increase in TSS of microwave pasteurization treatments was observed. The decrease in TSS was more prominent in the treatment with higher power level, similar Chia et al, (2012) observed that, UV irradiated pineapple juice exhibited a significant decreasing in TSS trend with increase in the treatment dose. 
Table.1 Effect of irradiation on physico-chemical composition of guava pulp

\begin{tabular}{|c|c|c|c|c|c|}
\hline Irradiation (KGy) & $\begin{array}{c}\text { Juice Recovery } \\
(\%)\end{array}$ & Pomace $(\%)$ & TSS $\left({ }^{\circ} \mathrm{B}\right)$ & $\begin{array}{l}\text { Titratable } \\
\text { acidity }(\%)\end{array}$ & $\begin{array}{l}\text { Ascorbic acid } \\
(\mathrm{mg} / 100 \mathrm{~g})\end{array}$ \\
\hline Control & $55.00 \pm 00^{\mathrm{a}}$ & $46.46 \pm 00^{\mathrm{a}}$ & $11.83 \pm 00^{\mathrm{a}}$ & $0.32 \pm 00^{\mathrm{a}}$ & $291.00 \pm 0.0^{\mathrm{a}}$ \\
\hline $\mathbf{0 . 5}$ & $54.02 \pm 1.48^{\mathrm{a}}$ & $43.74 \pm 0.91^{\mathrm{b}}$ & $12.14 \pm 0.5^{\mathrm{a}}$ & $0.32 \pm 0.01^{\mathrm{a}}$ & $283.00 \pm 2.00^{\mathrm{b}}$ \\
\hline $\mathbf{1 . 0}$ & $56.77 \pm 1.00^{\mathrm{b}}$ & $41.26 \pm 0.89^{\mathrm{c}}$ & $12.17 \pm 0.9^{\mathrm{a}}$ & $0.33 \pm 0.00^{\mathrm{a}}$ & $252.67 \pm 1.52^{\mathrm{c}}$ \\
\hline $\mathbf{1 . 5}$ & $56.30 \pm 1.50^{\mathrm{b}}$ & $41.23 \pm 1.05^{\mathrm{c}}$ & $12.51 \pm 0.3^{\mathrm{a}}$ & $0.31 \pm 0.02^{\mathrm{a}}$ & $231.33 \pm 2.08^{\mathrm{d}}$ \\
\hline LSD at 5\% & 2.20 & 1.56 & 0.95 & 0.02 & \\
\hline
\end{tabular}

Table.2 Effect of microwave pasteurization on physico-chemical composition of guava pulp

\begin{tabular}{|c|c|c|c|c|c|}
\hline Microwave (W) & $\begin{array}{c}\text { Juice Recovery } \\
(\%)\end{array}$ & Pomace $(\%)$ & TSS $\left({ }^{\circ} B\right)$ & $\begin{array}{c}\text { Titratable } \\
\text { acidity }(\%)\end{array}$ & $\begin{array}{c}\text { Ascorbic acid } \\
(\mathrm{mg} / 100)\end{array}$ \\
\hline Control & $(55.00 \pm 00)^{\mathrm{ac}}$ & $(46.46 \pm 00)^{\mathrm{a}}$ & $(11.83 \pm 00) \mathrm{c}$ & $(0.32 \pm 00)^{\mathrm{a}}$ & $(291.00 \pm 00)^{\mathrm{a}}$ \\
\hline $\mathbf{3 0 0}$ & $\left(57.71 \pm 1.07^{\mathrm{a}}\right.$ & $(40.36 \pm 0.73)^{\mathrm{b}}$ & $(13.05 \pm 0.5) \mathrm{a}$ & $(0.33 \pm 0.01)^{\mathrm{a}}$ & $(213.33 \pm 2.08)^{\mathrm{b}}$ \\
\hline $\mathbf{6 0 0}$ & $(61.37 \pm 0.65)^{\mathrm{b}}$ & $\left(37.46 \pm 1.11^{\mathrm{c}}\right.$ & $\begin{array}{c}(14.47 \pm 0.3) \\
\mathrm{ab}\end{array}$ & $(0.33 \pm 0.01)^{\mathrm{a}}$ & $(193.50 \pm 1.80)^{\mathrm{c}}$ \\
\hline $\mathbf{7 7 0 0}$ & $(59.02 \pm 2.97) \mathrm{ab}$ & $(36.76 \pm 0.84) \mathrm{c}$ & $\begin{array}{c}(13.64 \pm 0.72) \\
\mathrm{a}\end{array}$ & $(0.34 \pm 0.02)^{\mathrm{a}}$ & $(183.77 \pm 2.28)^{\mathrm{d}}$ \\
\hline LSD 5\% & 3.04 & 1.48 & 0.89 & 0.02 & 3.36 \\
\hline
\end{tabular}

Table.3 Effect of thermal pasteurization on physico-chemical composition of guava pulp

\begin{tabular}{|c|c|c|c|c|c|}
\hline Temperature $\left({ }^{\circ} \mathbf{C}\right)$ & $\begin{array}{c}\text { Pulp Recovery } \\
(\%)\end{array}$ & Pomace $(\%)$ & TSS $\left({ }^{\circ} \mathrm{B}\right)$ & $\begin{array}{c}\text { Titratable } \\
\text { acidity }(\%)\end{array}$ & $\begin{array}{c}\text { Ascorbic acid } \\
(\mathrm{mg} / 100 \mathrm{~g})\end{array}$ \\
\hline Control & $\left(55.00 \pm 0.0^{\mathrm{a}}\right.$ & $(46.46 \pm 00)^{\mathrm{a}}$ & $(11.83 \pm 00)^{\mathrm{a}}$ & $(0.32 \pm 00) \mathrm{a}$ & $\left(^{(291.00 \pm 00)^{\mathrm{a}}}\right.$ \\
\hline $\mathbf{7 0}$ & $\left(55.85 \pm 1.54^{\mathrm{ab}}\right.$ & $(42.03 \pm 0.62)^{\mathrm{b}}$ & $\begin{array}{c}(12.40 \pm 0.5) \\
\mathrm{ab}\end{array}$ & $\begin{array}{c}(0.35 \pm 0.01) \\
\mathrm{ab}\end{array}$ & $(149.33 \pm 1.10)^{\mathrm{b}}$ \\
\hline $\mathbf{8 0}$ & $(57.81 \pm 1.55)^{\mathrm{b}}$ & $40.97 \pm 1.02)^{\mathrm{c}}$ & $\begin{array}{c}(12.23 \pm 0.6) \\
\mathrm{ab}\end{array}$ & $\begin{array}{c}(0.35 \pm 0.02) \\
\mathrm{ab}\end{array}$ & $(139.03 \pm 1.62)^{\mathrm{c}}$ \\
\hline $\mathbf{9 0}$ & $(56.89 \pm 1.88)^{\mathrm{ab}}$ & $(39.37 \pm 0.85)^{\mathrm{b}}$ & $\begin{array}{c}(12.89 \pm 0.1) \\
\mathrm{b}\end{array}$ & $\begin{array}{c}(0.35 \pm 0.01) \\
\mathrm{b}\end{array}$ & $(131.00 \pm 1.96)^{\mathrm{d}}$ \\
\hline LSD 5\% & 2.72 & 1.38 & 0.77 & 0.03 & 2.62 \\
\hline
\end{tabular}


Table.4 Effect of irradiation pasteurization on various physicochemical of grape juice Grapes

\begin{tabular}{|l|c|c|c|c|c|c|}
\hline Irradiation & $\begin{array}{c}\text { Juice } \\
\text { Recovery }(\%)\end{array}$ & Pomace $(\%)$ & TSS $\left({ }^{\circ} \mathrm{B}\right)$ & $\begin{array}{c}\text { Titratable } \\
\text { acidity }(\%)\end{array}$ & $\begin{array}{c}\text { Ascorbic } \\
\text { Acid(mg/100g) }\end{array}$ & $\begin{array}{l}\text { Anthocyanin } \\
(\mathrm{mg} / 100 \mathrm{~g})\end{array}$ \\
\hline Control & $56.7 \pm 0.0 \mathrm{~b}$ & $43.3 \pm 0.0 \mathrm{~b}$ & $19.20 \pm 0 \mathrm{~b}$ & $0.35 \pm 0.0 \mathrm{a}$ & $8.0 \pm 0 \mathrm{~b}$ & $40.12 \pm 0 \mathrm{a}$ \\
\hline $\mathbf{0 . 5}$ & $(61.5 \pm 0.77 \mathrm{a}$ & $(37.8 \pm 1.40 \mathrm{c}$ & $19.47 \pm 0.54 \mathrm{~b}$ & $0.36 \pm 0.01 \mathrm{a}$ & $7.00 \pm 0.00 \mathrm{ab}$ & $35.57 \pm 0.25 \mathrm{~b}$ \\
\hline $\mathbf{1 . 0}$ & $62.7 \pm 1.03 \mathrm{a}$ & $35.4 \pm 0.94 \mathrm{a}$ & $20 . \pm 0.03 \mathrm{a}$ & $0.37 \pm 0.01 \mathrm{~b}$ & $6.5 \pm 0.50 \mathrm{a}$ & $(32.16 \pm 0.35 \mathrm{c}$ \\
\hline $\mathbf{1 . 5}$ & $62.4 \pm 0.63 \mathrm{a}$ & $(36.1 \pm 0 \mathrm{ac}$ & $20.15 \pm 0.26 \mathrm{a}$ & $0.37 \pm 0.00 \mathrm{~b}$ & $6.0 \pm 0.00) \mathrm{a}$ & $0.40 \pm 0.40 \mathrm{~d}$ \\
\hline LSD & 1.4 & 1.8 & 0.57 & 0.0172 & 1.41 & 0.55 \\
\hline
\end{tabular}

Table.5 Effect of microwave pasteurization on physico-chemical composition of grape juice

\begin{tabular}{|l|c|c|c|c|c|c|}
\hline Microwave & $\begin{array}{c}\text { Juice } \\
\text { Recovery }(\%)\end{array}$ & Pomace $(\%)$ & TSS $\left({ }^{\circ} \mathrm{B}\right)$ & $\begin{array}{c}\text { Titratable } \\
\text { Acidity }(\%)\end{array}$ & $\begin{array}{c}\text { Ascorbic } \\
\text { Acid(mg/100) }\end{array}$ & $\begin{array}{c}\text { Anthocyanin } \\
(\mathrm{mg} / 100 \mathrm{~g})\end{array}$ \\
\hline Control & $56.67 \pm 0.0 \mathrm{c}$ & $(43.33 \pm 0.0)$ & $(19.20 \pm 0) \mathrm{b}$ & $(0.35 \pm 0) \mathrm{a}$ & $(8.0 \pm 0.0 \mathrm{~b}$ & $40.12 \pm 0 \mathrm{a}$ \\
\hline $\mathbf{3 0 0}$ & $65.48 \pm 0.93 \mathrm{~b}$ & $(32.71 \pm 0.82)$ & $(18.77 \pm 0.32) \mathrm{b}$ & $(0.37 \pm 0.01) \mathrm{ab}$ & $(7.13 \pm 0.15 \mathrm{c}$ & $40.50 \pm 0.30 \mathrm{a}$ \\
\hline $\mathbf{6 0 0}$ & $68.79 \pm 1.05 \mathrm{a}$ & $(30.01 \pm 0.84)$ & $(20.53 \pm 0.45) \mathrm{a}$ & $(0.37 \pm 0.01) \mathrm{b}$ & $(6.76 \pm 0.05 \mathrm{ac}$ & $38.38 \pm 0.40 \mathrm{~b}$ \\
\hline $\mathbf{7 7 0 0}$ & $(67.78 \pm 1.12 \mathrm{a}$ & $(30.30 \pm 0.72)$ & $(20.88 \pm 0.68) \mathrm{a}$ & $(0.37 \pm 0.00) \mathrm{a}$ & $(6.44 \pm 0.38) \mathrm{a}$ & $37.48 \pm 0.40 \mathrm{c}$ \\
\hline LSD & 1.69 & 1.29 & 0.8274 & 0.018 & 0.39 & 0.60 \\
\hline
\end{tabular}

Table.6 Effect of thermal pasteurization on physico-chemical composition of grape juice

\begin{tabular}{|l|c|c|c|c|c|c|}
\hline Temperature & $\begin{array}{c}\text { Juice Recovery } \\
(\%)\end{array}$ & Pomace $(\%)$ & TSS $\left({ }^{\circ} \mathrm{B}\right)$ & $\begin{array}{c}\text { Titratable } \\
\text { acidity }(\%)\end{array}$ & $\begin{array}{c}\text { Ascorbic } \\
\text { acid } \\
(\mathrm{mg} / 100 \mathrm{~g})\end{array}$ & $\begin{array}{c}\text { Anthocyanin } \\
(\mathrm{mg} / 100)\end{array}$ \\
\hline Control & $56.67 \pm 0.0^{\mathrm{c}}$ & $43.33 \pm 0.0^{\mathrm{b}}$ & $19.20 \pm^{\mathrm{a}}$ & $0.35 \pm 0^{\mathrm{b}}$ & $(8.0 \pm 0.0) \mathrm{a}$ & $40.12 \pm 0.0 \mathrm{a}$ \\
\hline $\mathbf{7 0}$ & $63.05 \pm 0.65^{\mathrm{b}}$ & $35.50 \pm 1.02^{\mathrm{c}}$ & $16.47 \pm 08^{\mathrm{c}}$ & $0.37 \pm 0.01 \mathrm{a}$ & $(6.26 \pm 0.25)$ & $33.48 \pm 0.40 \mathrm{~b}$ \\
\hline $\mathbf{8 0}$ & $64.36 \pm 1.00^{\mathrm{a}}$ & $35.39 \pm 0.93^{\mathrm{a}}$ & $16.57 \pm 0.08^{\mathrm{c}}$ & $0.38 \pm 0.01 \mathrm{c}$ & $(5.50 \pm 0.20)$ & $31.40 \pm 0.40 \mathrm{c}$ \\
\hline $\mathbf{9 0}$ & $64.99 \pm 0.42^{\mathrm{a}}$ & $36.12 \pm 0.92^{\mathrm{a}}$ & $16.74 \pm 0.04^{\mathrm{b}}$ & $0.38 \pm 0.01 \mathrm{~b}$ & $(4.50 \pm 0.20)$ & $29.50 \pm 0.40 \mathrm{~d}$ \\
\hline LSD 5\% & 1.19 & 1.84 & 0.11 & 0.019 & 0.36 & 0.65 \\
\hline
\end{tabular}

\section{Titratable acidity}

Acidity is an important factor which affects the taste of several fruits; therefore, it is required to analyse the acidity content of any commodities. The titratable acidity of fresh guava and grape juice was observed $0.32 \%$ and $0.35 \%$ However after treatment it was observed that $0.34 \%, 0.37 \%$ and $0.34 \%$ in guava pulp where as $0.30 \%, 0.29 \%$ and $0.31 \%$ in grape juice acidity content marginal increased trend was observed in both of sample after the treatment of irradiation, thermal and microwave pasteurization respectively. So that data was shown in Table 2 , the increased in titratable acidity might be due to oxidation of reducing sugar can also be contributed to increase in the acidity of fruit juice during pasteurization (Kumar et al., 2017) (Table 4-6)

\section{Ascorbic acid (mg/100g)}

The ascorbic acid of the different treatments decreased with increase p0wer level because of these vitamins are heat sensitive nature, therefore ascorbic acid might be the reason for its reduction after the pasteurization treatment. Similar results in reduction of ascorbic acid were observed in thermal pasteurization of guava and grape. Microwave pasteurization at higher power levels 
$(>300 \mathrm{~W})$ was found to have a negative effect on ascorbic acid. However, treatment with microwave power level of $300 \mathrm{~W}$ showed a better retention of ascorbic acid content in guava and grape (215.0, $7.10 \mathrm{mg} / 100 \mathrm{~g})$ respectively. The results presented by Picouet et al., (2009), showed $100 \%$ and $83-85 \%$ ascorbic acid retention in apple puree and bell peppers and carrots processed by microwave under lower power levels. However, after 15 days of storage more than 50\% loss in Vitamin C content was observed. The reduction in ascorbic acid due to oxidation was the main reason behind the loss occurred after the high heat exposure followed by the refrigerated storage. Irradiation treatment less than $1 \mathrm{KGy}$ had a positive influence on the ascorbic acid. This study confirmed the beneficial effect of lower irradiation dose for fruit juices. Reason for the significant improvement of ascorbic acid might be due to partial conversion of the ascorbic acid to dehydroascorbic acid by the ionizing radiation (Kilcast, 1994).

\section{Anthocyanin (mg/L)}

Likewise, pure coloured grape contains highest anthocyanin $40.02 \mathrm{mg} / 100 \mathrm{ml}$ and it decrease with increase in the proportion of guava pulp. Positive influence of irradiation on anthocyanin was observed. Among all the treatments of irradiation dose of $1.0 \mathrm{KGy}$ gave the maximum anthocyanin content over the control. The effect of microwave treatments on anthocyanin content of coloured grape shows that there was a wide variation in anthocyanin content among different treatments. Increasing power level resulted in significant decrease of anthocyanin content. The highest loss was observed in treatment with power level of $900 \mathrm{~W}$. The highest retention was found in treatment with lower power, i.e., 300W. the anthocyanin content of thermal pasteurized grape juice decreased slightly with increase in temperature.
However, statistically there was no significant difference in anthocyanin content among the different temperature treatments (Table 3 ).

However, anthocyanin content of coloured grape juice decreased after the treatment with microwave, irradiation and thermal pasteurization treatment. This might be due to breakdown of monomeric glyosidic bond of anthocyanin.

In conclusion the pulp from guava fruits and juice from coloured grapes were extracted for the preparation of anthocyanin enriched guava nectar followed by different methods of pasteurization including thermal, microwave and irradiation. Salient findings of the investigation are summarized below.

There are three sets of pasteurization treatments, viz., irradiation $(0.5,1.0$ and 1.5 KGy) and microwave pasteurization (300, 600 , and $900 \mathrm{~W}$ ) for $1 \mathrm{Min} .30 \mathrm{Sec}$. and 10 Sec., thermal $\left(70^{\circ} \mathrm{C}, 80^{\circ} \mathrm{C}\right.$, and $90^{\circ} \mathrm{C}$ for 6,3 , and 2Min.). The optimized pasteurization treatment condition for the three pasteurization methods were $0.5 \mathrm{kGy}$, $600 \mathrm{~W} / \mathrm{ml}$ juice and $80^{\circ} \mathrm{Cfor} 3 \mathrm{Min}$. for irradiation, microwave and thermal pasteurization respectively which have been finalized by conducting preliminary experimentation. Hence these treatments was found to be significantly effect on retention of nutritional quality of juice for the preparation of anthocyanin enriched guava blended nectar.

\section{References}

AOAC., 1984. Official Methods of Analysis. 13th Edn., Association of Official Analytical Chemists, Washington, DC., USA., pp: 768-800.

Betancurt, P., Ares, M. I., Montalban, A., Arcia, P., Borthagaray, M. D. and Curutchet, A. (2009). Effect of ' irradiation as quarantine treatment on citrus fruit 
quality. In: International Nuclear Atlantic Conference. Rio de Janeiro, Brazil.

Bonaventura, S. and Russo, C. (1993). Refrigeration of blood oranges destined for transformation, pt. 1: tests on juice stability. Fruit processing (Germany).

AkesowanA., and Choonhahirun, A. (2013). Effect of enzyme treatment on guava juice production using response surface methodology. The Journal of Animal and Plant Sciences. 23: 114-120.

Chia, S. L., Rosnah, S., Noranizan, M. A. and Wan Ramli, W. D. (2012). The effect of storage on the quality attributes of ultraviolet-irradiated and thermally pasteurised pineapple juices. International Food Research Journal, 19(3): 10011010.

Kumar, S., Khadka, M., Mishra, R., Kohli, D. and Upadhaya, S. (2017). Effects of conventional and microwave heating pasteurization on physiochemical properties of pomelo (Citrus maxima) juice. Journal of Food Process Technology,8(7): 1-4.

Kilcast, D. (1994). Effect of irradiation on vitamins. Food Chemistry, 49(2): 157164.

Picouet, P. A., Landl, A., Abadias, M., Castellari, M. and Viñas, I. (2009). Minimal processing of a Granny Smith apple purée by microwave heating. Innovative Food Science and Emerging Technologies, 10(4): 545-550.

Queiroz, Y. S. (2006). Role of additives in vitro antioxidant activity of garlic products. Alimentos, 17:287-293.

Rasines-Perea, Z. and Teissedre, P. L. (2017). Grape polyphenols effects in human cardiovascular diseases and diabetes.
Molecules.22(8):68-76.

Rivas, A., Rodrigoa, D., Martı'nezaA,. BarbosaCa'novasb G. V. and Rodrigo. M. (2006). Effect of PEF and heat pasteurization on the physical-chemical characteristics of blended orange and carrot juice.. $L W T$ Food Science and Technology, 39(10): 1163-1170.

Ranganna S. (1999). Handbook of analysis and quality control for fruit and vegetable products. Tata McGraw-Hill Publishing Company, New Delhi, India. pp. 124-125.

Sethi, V. and Sethi, S. (2006). Processing of fruits and vegetables for value addition. Indus Publishing.

Vanamala, J., Reddivari, L., Yoo K.S., Pike, L.M. and Patil, B.S. (2007). Variation inthe content of bioactive flavonoids in different brands of orange and grapefruit juices. Journal of. Food Composition and Analysis, 19: 157-166.

Wilson, C.W. (1980). Tropical and Sub-tropical Fruits: composition, properties and uses. AVI publishing Inc West port Connecticut. pp. 279-295.

Lee, J., Wrolstad, R. E., and Durst, R. W. (2005). Tracking colour and pigment changes in anthocyanins products. Trends Food Science and Technology, 16, 423-428.

Yook, H. S. (2009). Effect of gamma irradiation on quality of kiwifruit (Actinidia deliciosa var. deliciosa cv. Hayward). Radiation Physics and Chemistry,78: 414-421.

Zahid Mehmood, (2008). Effect of Pasteurization and Chemical Preservatives on the Quality and Shelf Stability of Apple Juice. American Journal of Food Technology, 3: 147-153.

\section{How to cite this article:}

Ajit Kumar Singh, V. R. Sagar, Shalini G. Rudra, S. K. Singh and Sunil Pabbi. 2020. Influence of Pasteurization Methods on Nutritional Quality of Guava Pulp and Grape Juice. Int.J.Curr.Microbiol.App.Sci. 9(04): 590-598. doi: https://doi.org/10.20546/ijcmas.2020.904.072 